\title{
Pengembangan Media Bimbingan Videoedukasi untuk Meningkatkan Keterampilan Perencanaan Studi Lanjut bagi Siswa Kelas 9 SMP
}

\author{
M. Nana Yuhana*, Muslihati Muslihati, Lutfi Fauzan \\ Universitas Negeri Malang, Jl. Semarang No. 5 Malang, Jawa Timur, Indonesia \\ *Penulis korespondensi, Surel: nanayuhana825@gmail.com
}

Paper received: 2-11-2021; revised: 17-11-2021; accepted: 23-11-2021

\begin{abstract}
This study aims to produce media products in the form of educational videos and guidebooks which are expected to improve the skills of planning further studies for junior high school students. This research method adopts the ADDIE research model in which there are 5 stages, namely: analysis, design, development, implementation, and evaluation stages. The process in product validation is carried out by means of expert tests, including material expert tests, media expert tests and prospective users (counselors). The results of the expert test assessment of the product will get a feasibility interpretation from decent to very feasible to be used as a medium in providing services to improve the planning skills of junior high school students.
\end{abstract}

Keywords: educational videos; advanced study planning; junior high school students

\begin{abstract}
Abstrak
Penelitian ini bertujuan untuk menghasilkan produk media berupa video edukasi "Plan Your Future"dan buku panduan yang diharapkan bisa meningkatkan keterampilan perencanaan studi lanjut siswa SMP, Metode penelitian ini mengadopsi model penelitian ADDIE yang mana ada 5 tahapan yaitu: tahap analisis, desain, pengembangan, implementasi, dan evaluasi. Adapun proses dalam validasi produk dilakukan dengan cara uji ahli antara lainnya uji ahli materi, uji ahli media serta uji calon pengguna (konselor). Hasil dari penilaian uji ahli terhadap produk akan mendapatkan interpretasi kelayakan dari layak sampai sangat layak untuk dijadikan media dalam memberikan layanan guna meningkatkan keterampilan perencanaan studi lanjut siswa SMP.
\end{abstract}

Kata kunci: video edukasi; perencanaan studi lanjut; siswa SMP

\section{Pendahuluan}

Siswa SMP (Sekolah Menengah Pertama) termasuk individu yang memiliki rentan usia 15 - 18 tahun. Pada usia tersebut individu memasuki tahap perkembangan remaja. Remaja memiliki perkembangan yang harus dilewati pada periode berakhirnya masa anak - anak hingga dewasa awal. Tugas perkembangan yang dimaksud adalah mempersiapkan kewajiban, peran, tuntutan dan pilihan yang akan ada di masa depan. Sebagaimana yang diungkapkan Elizabeth B. Hurlock dalam (Kumara, 2019) masa remaja adalah dimana mereka mulai perlahan mengungkap masa depan yang akan dilewati dengan sungguh - sungguh, serta akan memberikan lebih banyak perhatian kepada pilihan kehidupan yang akan dijalani di masa depan. Lapangan pendidikan merupakan salah satu yang akan mendapatkan banyak perhatian dari remaja. Oleh karena itu pendidikan sangat penting bagi remaja untuk dapat meningkatkan taraf hidup, mendapatkan banyak pengetahuan, keterampilan, sikap, dan kecakapan yang didapat dari belajar dan pengalaman untuk mempertahankan hidup dan mencapai tujuan di masa depan. 
Pada umumnya di masa remaja perencanaan karir menjadi salah satu hal yang penting, pada saat itu remaja atau individu mulai mempersiapkan diri dengan mengeksplorasi kemampuan, minat, bakat, dan peluang untuk dipersiapkan dalam eksplorasi karir. (Bardick et al., 2004), dengan implementasinya berupa tindakan dalam menentukan pilihan pendidikan lanjutan yang sesuai dengan potensi diri, bakat, dan minat yang dimiliki setiap individu, seperti di dalam SKKPD bahwa siswa SMP memiliki tugas perkembangan antara lainnya wawasan dan kesiapan karir yang mana siswa diharapkan sudah bisa mengidentifikasikan berbagai macam pekerjaan, dan pendidikan selanjutnya yang mengandung relevansi dengan diri sendiri, menjadi masalah jika siswa SMP belum mengenal pekerjaan ataupun pendidikan serta jurusan pada sekolah selanjutnya ditambah lagi selama menempuh pendidikan di SMP siswa tidak mendapatkan layanan yang memadai guna membantu dalam mengenali potensi diri contohnya saja bakat dan minat kemudian dengan pemahaman yang kurang siswa menentukan pilihan pendidikan lanjutan bagi dirinya.

Siswa SMP sekarang ini banyak yang tidak mengerti dengan perencanaan studi lanjut, masih ada siswa yang menentukan studi lanjutnya dengan hanya berdasarkan sekolah yang bagus, ikut ajakan teman, dan pilihan orang tua tanpa mengetahui minat dan bakat siswa tersebut. Berdasarkan observasi yang dilakukan oleh (Jannah, 2015) kepada siswa kelas IX di SMP 2 Malang menunjukkan banyak dari siswa SMP yang masih mengalami kesulitan menentukan pilihan pendidikan lanjutan, serta ditambah lagi dengan banyak pengakuan dari siswa jika mereka tidak mengetahui tentang pendidikan lanjutan yang akan mereka pilih setelah menyelesaikan pendidikan di jenjang SMP, diperkuat juga oleh temuan dari (Ghassani \& Anwar, 2020) pada tahun 2017 yang dilakukan kepada siswa SMP swasta yang ada di kota Malang. Hasil yang didapatkan adalah hanya 6 siswa yang memiliki kejelasan dalam perencanaan karir setelah jenjang SMP dari 30 siswa kelas IX yang melakukan tes skala perencanaan karir dan diwawancarai secara mendalam. Masih banyak dari siswa yang menentukan pilihan studi lanjut tidak sesuai dengan apa yang ada dalam mereka contohnya bakat, minat dan pekerjaan di masa depan yang diinginkan. Dapat disimpulkan bahwa masih banyak siswa yang memilih perencanaan studi lanjut yang rendah.

Perencanaan karir merupakan tahapan individu merencanakan dalam menentukan peluang, kesempatan, informasi berkaitan dengan karir dalam jangka waktu yang panjang maupun pendek. Menurut Frank Parson dalam (Atmaja, 2014) perencanaan karir merupakan salah satu cara dalam membantu siswa untuk memilih salah satu bidang karir yang sesuai dengan potensi yang mereka miliki sehingga dapat memberikan hasil yang cukup meyakinkan pada bidang pekerjaan nantinya. Menurut Gysbers (dalam Rowland, 2004) banyak remaja dan juga anak - anak tidak dapat membuat keputusan karir yang tepat dengan hanya berdasarkan pada pengalaman hidup yang sudah dilalui.

Dukungan dan eksplorasi sangat dibutuhkan dengan bentuk berupa kurikulum dan program bimbingan karir guna membantu siswa dalam menentukan arah karir yang tepat bagi dirinya di masa mendatang. Perencanaan studi lanjut merupakan keterampilan dan kecakapan yang dimiliki oleh siswa dalam menentukan langkah - langkah kedepannya untuk mencapai tujuan yang sudah direncanakan sesuai dengan pengetahuan dan pemahaman diri sendiri, pekerjaan atau pendidikan serta penggunaan penalaran yang benar antara diri sendiri dan dunia kerja. Oleh karena itu sangat diperlukan media layanan bimbingan yang interaktif, inovatif dan efisien guna meningkatkan perencanaan studi lanjut siswa SMP dengan begitu 
akan dapat mengurangi jumlah siswa yang tidak mengerti dan tidak melakukan perencanaan studi lanjut.

Pesatnya perkembangan teknologi yang ada sekarang ini mendukung adanya pengembangan layanan ke arah yang bersifat digital seperti video karena dianggap lebih efisien dan dapat menarik minat siswa untuk memperhatikan. siswa SMP sendiri masuk dalam kategori anak - anak hingga dewasa awal yang mana karakteristik dari siswa adalah cenderung menyukai pembelajaran yang bervariatif tidak hanya monoton dengan penjelasan dari guru saja dengan begitu siswa akan menerima dengan baik informasi yang disampaikan oleh guru atau konselor yang ada di kelas, ditambah lagi dengan sistem pembelajaran yang online media video edukasi "Plan Your Future" sangat sesuai untuk dijadikan media pembelajaran saat ini, didukung juga dengan hasil penelitian dari (Muttaqin et al., 2017) yang menghasilkan bahwa layanan bimbingan konseling dengan media video mendapatkan lebih banyak perhatian dari siswa daripada dengan layanan bimbingan yang menggunakan media selain video, dengan begitu layanan bimbingan dengan media video memberikan keefektifan kepada pemahaman siswa terhadap informasi yang diberikan oleh guru di depan kelas.

Oleh karena itu media video edukasi "Plan Your Future" cocok untuk membantu siswa SMP meningkatkan keterampilan perencanaan karir atau perencanaan studi lanjut, dengan video yang berisikan kiat - kiat jitu untuk bisa merencanakan studi lanjut dengan mudah dan efektif, terdapat informasi mengenai pendidikan lanjutan formal maupun non-formal untuk memberikan banyak informasi bagi siswa dalam merencanakan studi lanjutnya, tidak lupa juga di dalam video dilengkapi kata - kata motivasi untuk menggugah semangat siswa untuk lebih mempersiapkan diri untuk studi lanjut didukung dengan desain yang menarik guna menambah daya tarik siswa untuk lebih memperhatikan.

\section{Metode}

Prosedur penelitian menggunakan model pengembangan ADDIE dengan 5 tahap yaitu analisis (analysis), desain (design), pengembangan (development), implementasi (implementation), dan evaluasi (evaluation). Menurut Branch (2009) salah satu model yang paling efektif dalam menghasilkan sebuah produk ialah model pengembangan ADDIE, dikarenakan model pengembangan ini memiliki pedoman kerangka kerja untuk situasi yang sangat kompleks, sehingga mengembangkan produk pendidikan dengan model ini sangat tepat. Penggunaan model pengembangan ini dikarenakan tahapan yang lebih ringkas dan efektif untuk digunakan, peneliti sedikit melakukan modifikasi pada tahapan pengembangan karena untuk menyesuaikan dengan situasi pada saat itu.

Uraian prosedur sebagai berikut: (1) Analisis, melakukan pengumpulan data dari konselor atau guru yang ada di SMPN 6 Kota Malang dengan menggunakan teknik wawancara. Peneliti juga melakukan kajian literatur dari penelitian sebelum - sebelumnya yang berkaitan dengan penelitian ini. (2) Tahap desain, Peneliti merumuskan pengembangan produk media yang dikembangkan dan rencana desain. Aspek - aspek yang perlu diperhatikan untuk mengembangkan produk, termasuk materi yang cocok, dan pemilihan karakter video yang cocok untuk siswa SMP, (3) Tahap selanjutnya adalah pengembangan, dengan pengembangan produk utama yaitu media video edukasi "Plan Your Future" dan juga produk buku panduan, dalam prosesnya produk melewati uji ahli media dan materi guna menghasilkan penilaian dan masukan untuk perbaikan produk, (4) Tahap implementasi berupa mengujicobakan produk kepada calon pengguna yaitu konselor atau guru BK yang ada di sekolah yang bertujuan untuk 
mendapatkan penilaian dan masukan. Kegiatan ini juga berguna untuk menguji kelayakan produk untuk dijadikan media layanan bimbingan nantinya, (5) Tahap akhir berupa evaluasi, melakukan evaluasi dan perbaikan terhadap produk yang dikembangkan sesuai dengan kritik dan saran konselor atau guru BK dengan tujuan mendapatkan produk yang bernilai baik dan efektif untuk pemberian layanan kedepannya.

Subjek pada uji ahli produk meliputi uji ahli materi, media, dan uji calon pengguna. Ahli materi adalah dosen BK dengan kualifikasi dosen tersebut ahli dan sangat menguasai materi yang terdapat pada buku panduan, ahli media adalah dosen dengan kualifikasi ahli dalam hal desain media video untuk menguji media ke dalam buku panduan, sedangkan uji calon pengguna adalah guru BK (konselor) lulusan S1 Bimbingan dan Konseling yang ada di SMP 6 Kota Malang yang memiliki kualifikasi dalam melaksanakan layanan dengan menggunakan media video.

Penelitian ini menggunakan dua analisis data pertama data kualitatif yang dikumpulkan selama penelitian berasal dari angket uji coba yang berupa kritik, saran, dan komentar hal ini bertujuan untuk perkembangan dari produk yang mana diperoleh dari ahli materi, media, dan calon pengguna. Data yang diperoleh selanjutnya dianalisis dengan cara: (1) mengumpulkan data berupa kritik, komentar dan saran yang diperoleh dari setiap uji ahli dan calon pengguna (2) kemudian menghimpun, menyeleksi, dan mengklasifikasikan data berdasarkan kelompok uji, (3) menganalisis data untuk dijadikan rumusan dalam merevisi produk yang dikembangkan. Kedua Data kuantitatif yang dianalisis berasal dari instrumen penilaian hasil uji coba produk dan buku panduan yang dikembangkan. Skala dengan rentang $1-4$ yang ada pada instrumen penilaian akan menghasilkan data skor penilaian dari ahli materi, ahli media, dan juga guru Bimbingan dan Konseling yang ada di SMPN 6 Kota Malang. Kedua analisis data tersebut berdasarkan spesifikasi produk yang diharapkan yaitu: kegunaan, kemudahan, ketepatan, dan kemenarikan.

Rumus yang digunakan untuk mengolah data kuantitatif sebagai berikut.

Persentase Kelayakan (\%) $=\frac{\text { Skor yang didapatkan }}{\text { Skor maksimal }} \times 100 \%$

Pencarian presentase dimaksudkan untuk mengetahui status hasil yang diharapkan sehingga dapat mengetahui status kelayakannya.

Tabel 1. Kriteria Kelayakan Produk

\begin{tabular}{ccc}
\hline Persentase Pencapaian & Kategori/Intepretasi & Kualifikasi \\
\hline $76-100 \%$ & Sangat Layak & Sangat Valid / Tidak Revisi \\
$56-75 \%$ & Layak & Valid / Revisi Sebagian \\
$40-55 \%$ & Cukup & Kurang Valid / Revisi Sebagian \\
$0-39 \%$ & Kurang Layak & Tidak Valid / Revisi Keseluruhan \\
\hline
\end{tabular}

\section{Hasil dan Pembahasan}

\subsection{Hasil}

Produk yang dihasilkan pada penelitian dan pengembangan ini berupa produk media video edukasi "Plan Your Future" dan buku panduan, video edukasi "Plan Your Future" yang 
dikembangkan berjudul Plan Your Future seperti artinya yang mana video ini akan membantu siswa dalam merencanakan masa depannya dalam hal ini adalah studi lanjut, serta produk buku panduan yang berjudul Buku Panduan Video edukasi "Plan Your Future" dalam Pelaksanaan Bimbingan Klasikal untuk Meningkatkan Keterampilan Perencanaan Studi Lanjut Siswa SMP. Desain produk video menggunakan web Renderforest.com dan juga aplikasi Filmora sedangkan buku panduan didesain dengan Ms.Word serta website Canva.com, dengan karakter video berupa animasi kartun dengan latar berwarna-warni yang mana cocok untuk karakter anak SMP yang mana hal tersebut berguna juga untuk menarik perhatian dari siswa, untuk desain buku panduan yang berwarna dengan kombinasi hijau tosca, biru dan putih memberikan efek cerah agar tidak membosankan. Produk media video edukasi "Plan Your Future" dan buku panduan digunakan konselor di sekolah sebagai alternatif saat melaksanakan layanan bimbingan karir.

Video edukasi "Plan Your Future" yang dikembangkan terdiri dari 3 part video, video part 1 berisikan tentang informasi mengenai bimbingan karir serta tujuan, pengertian perencanaan studi lanjut beserta tujuannya dan aspek dari perencanaan studi lanjut yaitu aspek penerimaan diri, video part 2 berisikan informasi mengenai pendidikan lanjutan seperti: macam pendidikan lanjutan setelah SMP, karakteristik, macam jurusan, sistem pendaftaran, ditambah sedikit informasi tentang pendidikan non-formal, sedangkan video part 3 berisikan informasi terkait cara-cara membuat perencanaan studi lanjut. Didukung juga adanya katakata motivasi yang ada pada video guna memberikan semangat kepada siswa. Buku panduan yang dikembangkan terdiri dari kata pengantar sampai lampiran dengan isi buku panduan pada bab 1 sampai 4. Buku panduan ini dikembangkan dengan tujuan untuk pedoman konselor untuk melaksanakan layanan bimbingan dengan menggunakan media video, (a) bab 1 berisikan pendahuluan, tujuan dari buku panduan, sasaran pengguna dan prasyarat penggunaan,(b) bab 2 berisikan tentang pengertian perencanaan studi lanjut, layanan bimbingan karir dengan menggunakan media video serta informasi tentang media video, (c) bab 3 menjelaskan tentang tujuan umum dari buku panduan dan juga petunjuk pelaksanaan layanan bimbingan menggunakan media video edukasi, (d) bab 4 berisikan penutup dari buku panduan ini, serta pada bagian akhir ada halaman lampiran yang berisikan RPLBK yang bertujuan sebagai alternatif konselor dalam melaksanakan layanan dengan menggunakan media video edukasi "Plan Your Future" yang sudah dikembangkan.

Hasil penilaian dari uji ahli materi, uji ahli media dan uji calon pengguna terhadap media video edukasi "Plan Your Future" dan buku panduan dapat dilihat di tabel 2.

Tabel 2. Hasil Penilaian Uji Ahli Materi, Uji Ahli Media, dan Uji Calon Pengguna

\begin{tabular}{|c|c|c|}
\hline Ahli Materi & Ahli Media & Calon Pengguna (Konselor) \\
\hline $\begin{array}{l}\text { Hasil penilaian uji ahli } \\
\text { terhadap materi buku } \\
\text { panduan mendapatkan skor } \\
\text { persentase 93,4\% dengan } \\
\text { interpretasi produk "sangat } \\
\text { layak" }\end{array}$ & $\begin{array}{l}\text { Hasil penilaian uji ahli } \\
\text { media video } \\
\text { mendapatkan skor } \\
\text { persentase } 90 \% \text { dengan } \\
\text { interpretasi produk } \\
\text { "sangat layak" }\end{array}$ & $\begin{array}{l}\text { Hasil penilaian calon pengguna } \\
\text { terhadap produk buku panduan dan } \\
\text { media video mendapatkan skor } \\
\text { persentase 95\% dengan interpretasi } \\
\text { produk "sangat layak" }\end{array}$ \\
\hline $\begin{array}{l}\text { link video perlu dimasukkan } \\
\text { di panduan untuk } \\
\text { memudahkan pengguna } \\
\text { dalam melihat video yang } \\
\text { akan digunakan. }\end{array}$ & $\begin{array}{l}\text { Pada tahap akhir video, } \\
\text { perlu diberikan } \\
\text { penguatan berupa } \\
\text { kalimat penyemangat, }\end{array}$ & $\begin{array}{l}\text { Video dan buku panduan sangat } \\
\text { menarik dan mudah untuk } \\
\text { digunakan oleh konselor. Isi yang } \\
\text { disampaikan juga saya rasa akan } \\
\text { menarik minat siswa untuk }\end{array}$ \\
\hline
\end{tabular}




\begin{tabular}{|c|c|c|}
\hline Ahli Materi & Ahli Media & Calon Pengguna (Konselor) \\
\hline & $\begin{array}{l}\text { sehingga tidak langsung } \\
\text { pada "sampai jumpa" }\end{array}$ & \multirow{2}{*}{$\begin{array}{l}\text { menyimak dan memperhatikan } \\
\text { serta menambah pengetahuan } \\
\text { mereka tentang persiapan studi } \\
\text { lanjut. }\end{array}$} \\
\hline $\begin{array}{l}\text { pembagian layanan } \\
\text { bimbingan untuk pertemuan } \\
2 \text { dipecah saja sesuai satu } \\
\text { tujuan utama yakni informasi } \\
\text { karier, sedangkan untuk } \\
\text { pengambilan keputusan } \\
\text { dimasukkan ke pertemuan } 3 \\
\text { sekaligus terminasi. }\end{array}$ & $\begin{array}{l}\text { Apakah bisa di video } \\
\text { kedua diberikan dulu } \\
\text { ulasan di awal tentang } \\
\text { video sebelumnya, agar } \\
\text { tidak terkesan ujug-ujug } \\
\text { muncul sekolah lanjutan. }\end{array}$ & \\
\hline $\begin{array}{l}\text { Tolong diteliti terkait } \\
\text { kesalahan pengetikan }\end{array}$ & $\begin{array}{l}\text { Kemudian warna video } \\
\text { ini masih kurang cerah }\end{array}$ & \\
\hline $\begin{array}{l}\text { Evaluasi hasil ini melihat } \\
\text { ketercapaian tujuan umum } \\
\text { dan tujuan khusus, apakah } \\
\text { pertanyaan ini bisa mengukur } \\
\text { ketercapaian tujuan umum } \\
\text { dan khusus? } \\
\text { Jika ini rancu dengan lembar } \\
\text { kerja, maka ambil salah satu } \\
\text { saja. }\end{array}$ & $\begin{array}{l}\text { Pada bagian video ini } \\
\text { suaranya tidak terlalu } \\
\text { jelas }\end{array}$ & \\
\hline
\end{tabular}

\subsection{Pembahasan}

Penelitian dan pengembangan ini menghasilkan produk berupa media video edukasi "Plan Your Future" dan buku panduan yang nantinya akan diberikan kepada konselor di sekolah, topik yang ada dalam video dan buku panduan menangani rencana studi lanjut sesuai dengan data penelitian di SMP 6 Kota Malang. Wawancara dengan guru BK (Konselor) yang ada di sekolah merupakan teknik pengumpulan data yang digunakan pada penelitian ini, dari hasil wawancara dapat disimpulkan bahwa perlunya media video edukasi "Plan Your Future" guna meningkatkan keterampilan perencanaan studi lanjut siswa SMP. Siswa SMP menginjak fase dimana mereka dihadapkan dengan pilihan - pilihan di masa depan seperti halnya pilihan pendidikan lanjutan dan hal itu sangat penting bagi siswa untuk lebih mempersiapkan rencana kedepannya seperti dijelaskan dalam SKKPD bahwa siswa SMP memiliki tugas perkembangan antara lainnya wawasan dan kesiapan karir yang mana siswa diharapkan sudah bisa mengidentifikasikan berbagai macam pekerjaan, dan pendidikan selanjutnya.

Perencanaan studi lanjut (karir) adalah kecakapan individu dalam mengidentifikasi semua langkah - langkah dan perencanaan rencana - rencana guna proses pencapaian tujuan karir individu dalam hal rencana pekerjaan maupun pilihan pendidikan di masa depan. Penting sekali bagi siswa untuk bisa melakukan perencanaan studi lanjut dengan baik dan benar karena hal itu berguna untuk pemilihan pendidikan lanjutan yang sesuai dengan diri siswa masing-masing. Oleh karena itu siswa sekarang sangat membutuhkan layanan bimbingan dengan topik utama perencanaan studi lanjut dengan menggunakan media yang inovatif dan menarik seperti video edukasi untuk memberikan keefektifan dalam pelaksanaannya.

Video edukasi "Plan Your Future"yang dikembangkan berisikan materi tentang perencanaan studi lanjut yaitu: pengertian perencanaan studi lanjut, tujuan perencanaan studi lanjut, dan aspek-aspek dari perencanaan studi lanjut. Jordan (Atmaja, 2014) bahwa ada 3 aspek dari perencanaan studi lanjut antara lainnya; aspek pemahaman diri, aspek informasi 
karir, aspek perencanaan pengambilan keputusan, materi ini penting diberikan kepada siswa SMP khususnya karena seperti hasil wawancara mendapatkan bahwa sekitar 50\% siswa SMP tidak mengerti dengan perencanaan studi lanjut. Produk video edukasi “Plan Your Future”yang dikembangkan juga memiliki desain yang menarik dari segi warna, karakter animasi kartun, dan backsound, hal ini memberikan dampak kepada perhatian dan antusias siswa seperti hasil penelitian dari (Muttaqin et al., 2017) yang menghasilkan bahwa layanan bimbingan konseling dengan media video mendapatkan lebih banyak perhatian dari siswa daripada dengan tidak menggunakan media video, karena menggunakan media video memberikan keefektifan kepada pengetahuan dan pemahaman siswa mengenai informasi yang diberikan oleh guru BK. Penelitian ini juga mengembangkan produk buku panduan untuk konselor di sekolah dengan tujuan sebagai petunjuk dalam melaksanakan layanan yang menggunakan media video edukasi.

Produk buku panduan ini dikembangkan dengan tujuan memudahkan konselor untuk melaksanakan layanan dengan menggunakan media video edukasi "Plan Your Future"' Plan Your Future". Buku panduan memiliki sekitar 50 halaman yang terdiri dari beberapa bagian antara lainnya; (a) bab 1 berisikan pendahuluan, tujuan dari buku panduan, sasaran pengguna dan prasyarat penggunaan,(b) bab 2 berisikan tentang pengertian perencanaan studi lanjut, layanan bimbingan karir dengan menggunakan media video serta informasi tentang media video, (c) bab 3 menjelaskan tentang tujuan umum dari buku panduan dan juga petunjuk pelaksanaan layanan bimbingan menggunakan media video edukasi, (d) bab 4 berisikan penutup dari buku panduan ini, serta pada bagian akhir ada halaman lampiran yang berisikan RPLBK yang bertujuan sebagai alternatif konselor dalam melaksanakan layanan dengan menggunakan media video edukasi "Plan Your Future"yang sudah dikembangkan.

Kedua produk yang dikembangkan oleh peneliti sudah melewati tahapan uji ahli materi, uji ahli media, dan juga uji calon pengguna. Hasil uji ahli materi mendapatkan skor 93,4\% dengan demikian materi yang ada dalam produk interpretasinya sangat layak, hasil uji media mendapatkan skor 90\% dengan interpretasi sangat layak dan hasil uji calon pengguna mendapatkan skor 95\% dengan interpretasi sangat layak untuk kedua produk, dari hasil tersebut maka produk buku panduan dan juga video edukasi "Plan Your Future" sangat layak untuk digunakan saat pemberian layanan bimbingan, (Muttaqin et al., 2017) melakukan penelitian dengan hasil yang menunjukkan bahwa dengan menggunakan video interaktif dan live modeling sangat efektif untuk meningkatkan pemahaman karier siswa SMP.

Buku panduan dikembangkan bertujuan untuk petunjuk melaksanakan bimbingan karir, bimbingan karier merupakan proses pemberian bantuan kepada siswa dengan tujuan memperoleh penyesuaian diri, pemahaman akan dunia kerja maupun dunia pendidikan dan juga dapat membantu siswa dalam menentukan pilihan perencanaan karier. Bimbingan karir sendiri penting bagi perkembangan karir siswa khususnya dalam bidang pendidikan lanjutan, dengan bimbingan karir yang diberikan kepada siswa dapat meningkatkan siswa dalam hal pemahaman karir (Atmaja, 2014). Buku panduan pada bagian lampiran dilengkapi RPLBK yang bisa dijadikan pedoman ataupun alternatif konselor ketika melaksanakan layanan bimbingan karir, dapat disimpulkan bahwa produk buku panduan yang dikembangkan memiliki nilai lebih dalam membantu konselor.

Penelitian ini mengembangankan produk dengan melalui beberapa tahapan, dari melakukan wawancara dengan konselor yang ada di sekolah, kemudian merancang desain 
produk, melakukan uji ahli yang terdiri dari; uji ahli materi, uji ahli media, dan uji calon pengguna. Widya Multisari, S.Pd sebagai dosen uji ahli materi, M.Pd dosen Bimbingan dan Konseling, Dr. Indriyana Rachmawati, M.Pd sebagai dosen uji ahli materi, sedangkan untuk uji calon pengguna dilakukan oleh Shinta Amelia S.Pd sebagai konselor di SMP 6 Kota Malang. Dari tahapan uji produk mendapatkan data numerik dan data verbal yang nantinya akan dijadikan patokan dalam memperbaiki produk yang dikembangkan. Hasil yang didapat dari tahap uji produk adalah interpretasi "sangat layak" untuk media video edukasi "Plan Your Future" dan buku panduan, produk media video edukasi dan buku panduan yang digunakan untuk layanan bimbingan karir dengan tujuan meningkatkan keterampilan perencanaan studi lanjut siswa SMP sangat layak digunakan.

Penelitian serupa dilakukan oleh (Sari, 2019) pengembangan media berupa video tutorial sebagai media informasi studi lanjut, media yang dikembangkan lebih mengarah kepada informasi studi lanjut setelah jenjang SMP, fokus penelitian dari penelitian dan pengembangan ini menjadi perbandingan penelitian ini terletak pada fokus penelitian yang mana penelitian ini fokus pada pengembangan media berupa video edukasi yang bertujuan untuk meningkatkan keterampilan perencanaan studi lanjut siswa SMP sedangkan penelitian sebelumnya berfokus pada pengembangan media video tutorial sebagai informasi studi lanjut. Kekurangan dari penelitian ini adalah produk yang dikembangkan tidak sampai diujicobakan secara langsung kepada siswa untuk dapat mengukur keefektifan produk dikarenakan situasi pandemi sekarang ini.

\section{Simpulan}

Penelitian ini menghasilkan produk berupa video edukasi "Plan Your Future" dan buku panduan dengan keberterimaan sangat layak sesuai dengan unsur ketepatan, kegunaan, kemenarikan, dan kemudahan, peneliti melakukan penelitian dengan menggunakan metode ADDIE yang dalam prosesnya masih terdapat kekurangan yakni tidak melakukan uji langsung kepada siswa, maka dari itu saran untuk peneliti selanjutnya untuk bisa melanjutkan ke tahap selanjutnya yakni menguji keefektifan produk video edukasi "Plan Your Future" dan buku panduan untuk meningkatkan keterampilan perencanaan studi lanjut kepada siswa SMP secara langsung.

\section{Daftar Rujukan}

Atmaja, T. T. (2014). Upaya Meningkatkan Perencanaan Karir Siswa Melalui Bimbingan Karir dengan Penggunaan Media Modul. PSIKOPEDAGOGIA Jurnal Bimbingan Dan Konseling, 3(2), 57. https://doi.org/10.12928/psikopedagogia.v3i2.4466

Arikunto, S. 1993. Prosedur Penelitian Suatu Pendekatan Praktik (edisi revisi II, Cetakan Kesembilan). Jakarta: Penerbit Rineka Cipta.

Branch, Robert. (2009). Instructional Design The ADDIE Approach. USA: Springer.

Bardick, A. D., Bernes, K. B., Magnusson, K. C., \& Witko, K. D. (2004). Junior High Career Planning: What Students Want. Junior High Career Planning: What Students Want., 38(2), 104-117.

Ghassani, M., \& Anwar, Z. (2020). Meningkatkan Kematangan Karir Siswa SMP Melalui Pelatihan Perencanaan Karir. Jurnal Intervensi Psikologi, 12(2), 122.

Janah, R. R. (2015). Modul Perencanaan Karir untuk Meningkatkan Keterampilan Mengambil Keputusan Karir Siswa SMP pada Sekolah Lanjutan. SKRIPSI Jurusan Bimbingan dan Konseling \& Psikologi-Fakultas Ilmu Pendidikan UM.

Muttaqin, R., Wagimin, \& Tadjri, I. (2017). Keefektifan Layanan Informasi Karier Berbantuan Video Interaktif dan Live Modeling untuk Meningkatkan Pemahaman Karier Siswa SMP. Jurnal Bimbingan Konseling, 6(2), 174-179. http://journal.unnes.ac.id/sju/index.php/jubk\%0AKeefektifan 
Jurnal Pembelajaran, Bimbingan, dan Pengelolaan Pendidikan, 1(11), 2021, 897-905

Ria Kumara, A., \& Lutfiyani, V. (2019). Strategi Bimbingan Dan Konseling Komprehensif Dalam Perencanaan Karir Siswa Smp. G-Couns: Jurnal Bimbingan Dan Konseling, 1(2), 180-191. https://doi.org/10.31316/g.couns.v1i2.46

Rowland, K. D. 2004. Career Decision-Making Skills of High School Students in Bahamas. Journal of Career Development vol. 31. London: Sage Publication

Sari, N. R. (2019). Pengembangan video tutorial perencanaan karier sebagai media informasi studi lanjut untuk siswa Sekolah Menengah Pertama (Doctoral dissertation, Universitas Negeri Malang). 